\title{
Perfis femininos no romance $A$ maçã no escuro, de Clarice Lispector ${ }^{1}$
}

Marilia Murta de Almeida ${ }^{2}$

\section{Resumo:}

Este artigo propõe uma análise das figuras femininas no romance $A$ maçã no escuro, de Clarice Lispector. Tal análise busca explicitar o modo como as personagens femininas se relacionam com o protagonista Martim, trazendo à luz estruturas marcadamente conhecidas socialmente como "lugares" femininos, formas típicas de expressão e de dominação da mulher, assim como a saída vislumbrada pelo desenlace do texto para tal situação.

\begin{abstract}
:
This article proposes an analysis of the female figures in Clarice Lispector's novel $A$ maça no escuro (published in English as The aplle in the dark). This analysis seeks to make explicit the way in which the female characters relate to the protagonist Martim, bringing to light structures that are socially known as female "places", typical forms of expression and domination of women, as well as the exit glimpsed by the outcome of the text for such situation.
\end{abstract}

${ }^{1}$ Texto base para trabalho apresentado no I Encontro do Grupo de Trabalho Filosofia e Gênero da ANPOF, em 29 de novembro de 2017, na UNIRIO, Rio de Janeiro.

${ }^{2}$ Mestre em Filosofia pela UFMG, professora de filosofia e doutoranda em Teologia na FAJE - Faculdade Jesuíta de Filosofia e Teologia, em Belo Horizonte. 
“E, num alívio que lhe pareceu

dever ter sido o do homem quando a mulher fora enfim criada - tirando-lhe enfim a liberdade e enfim impossibilitando-o de ser formidável ele já sorrindo, mal a ouvia." Clarice Lispector, em $A$ maçã no escuro

A obra de Clarice Lispector tem sido objeto de inúmeras análises desde o lançamento de seu primeiro romance em 1942. Dentro desse panorama, muito se disse sobre o feminino, seja sobre o modo como a autora aborda e expõe a condição feminina em suas personagens, seja sobre o caráter feminino da escrita da autora - a questão da "escrita feminina". Sobre este tema destacam-se os trabalhos de Hélène Cixous (1986, 1989), que defende a noção de escrita "feminina" como a escrita que estabelece outros modos, que não aqueles previstos nos códigos secularmente regulamentados da linguagem, como uma escrita furada, vazada, cujos furos são aberturas por onde passam os outros significados, a outra lógica, marcada pela presença da imagem, do simbólico, do desejo.

A própria Clarice se dedicou a escrever colunas femininas em revistas $^{3}$, deixando clara sua familiaridade com o que se convencionou chamar de universo feminino.

Antes de iniciar a análise das personagens femininas de $A$ maçã no escuro, cabe aqui um esclarecimento acerca da interpretação filosófica que tenho feito da obra de Clarice Lispector. Defendo que há uma visão de ser humano desenvolvida ao longo de toda a obra da autora, uma antropologia,

\footnotetext{
3“Entre mulheres", no jornal "Comício", em 1952, sob o pseudônimo de Tereza Quadros. "Correio feminino", no jornal "Correio da manhã", de 1959 a 1961, sob o pseudônimo de Helen Palmer. "Só para mulheres", no jornal "Diário da noite, de 1960 a 1961, como "ghostwriter" da atriz Ilka Soares. Duas seleções desses textos foram publicadas: LISPECTOR, Clarice. Correio feminino. Rio de Janeiro: Rocco, 2006, e LISPECTOR, Clarice. Só para mulheres. Rio de Janeiro: Rocco, 2008.
} 
de modo que podemos extrair da obra clariceana uma compreensão universalizável do humano. Assim, as personagens femininas que protagonizam todos os romances, com exceção de $A$ maçã no escuro, dizem mais sobre o humano do que sobre sua condição de mulher. Esta é, aliás, uma indicação para uma outra análise a ser feita em recorte feminista, o caráter universalizável da mulher na obra de Clarice Lispector, de modo a que possamos usar a palavra "mulher" como referente a "ser humano"4, como tem sido usada a palavra "homem" ao longo de tanto tempo. Como explicitarei mais à frente, este texto não trata dessa antropologia, faz antes um recorte ético em torno das relações de gênero.

No contexto geral da fortuna crítica de Clarice Lispector, muitos trabalhos tocam a fronteira com a filosofia. O universo de problemas filosóficos atingidos por Clarice Lispector é vasto, passando pela epistemologia - acesso à verdade, limites do conhecimento, limites da linguagem -, pela ética, pela ontologia, pela relação humano/divino, pela antropologia. Temos por exemplo os trabalhos clássicos de Benedito Nunes (1969, 1973), em que se dá a aproximação dos temas centrais da autora com as correntes existencialistas, em especial Sartre. Entre publicações recentes, cito o livro de Elton Tada (2017), em que o autor explicita a aproximação da obra clariceana ao universo religioso.

O romance $A$ maçã no escuro concentra em si todo esse universo de problemas, centralizado no percurso do protagonista. Como possíveis leituras que exploram esse universo, cito aqui três artigos: "Linguagem, cognição e referência em A maçã no escuro", de Alana Demétrio e Maria H. Costa (2015), que, como aponta o título, desenvolve uma análise da questão da linguagem tal como aparece no romance; "As margens filosóficas no

${ }^{4}$ Como nesta passagem do romance Uma aprendizagem ou o livro dos prazeres: "Aí estava o mar, a mais ininteligível das existências nãohumanas. E ali estava a mulher, de pé, o mais ininteligível dos seres vivos. Como o ser humano fizera um dia uma pergunta sobre si mesmo, tornara-se o mais ininteligível dos seres onde circulava sangue. Ela e o mar." (LISPECTOR, 1998, p. 78). 
romance A maçã no escuro, de Clarice Lispector", de Miriam Pires (publicação virtual, sem data), que identifica, como "margens filosóficas", o problema do discurso e do conhecimento, a revitalização dos sentidos, da percepção, assim como a ressignificação da história e da memória, ainda no escopo do problema do conhecimento, e a postulação de uma ética utópica; e "Crime e libertação: um estudo sobre $A$ maçã no escuro, de Clarice Lispector", de Júlio Vieira e Osmar Oliva (2011), sobre o problema do mal.

Passo agora ao desenvolvimento da análise pretendida. A maçã no escuro (LISPECTOR, 1998) é o único romance de Clarice Lispector em que o protagonista é um homem, o que determinou a sua escolha para esta análise, devido à percepção de que é justamente quando perdem seu lugar de protagonista que as personagens femininas de Clarice Lispector melhor revelam sua condição de mulher, falando aqui a partir de uma abordagem feminista que reconhece a condição da mulher como aquela do oprimido, para usar o vocabulário desenvolvido por Paulo Freire em toda a sua obra, desde A pedagogia do oprimido (1987).

Pois bem, em A maçã no escuro, o protagonista Martim vai percorrer uma jornada de transformação, de tom quase mítico, durante todo o percurso do romance. Jornada que tem seu início desencadeado por algo que se passa com uma mulher e que se desenvolve em meio a outras mulheres. Ou seja, é envolvido em relações com mulheres que Martim se transforma. A trajetória desse personagem é fascinante e diz respeito a todos nós - porque aqui é ele o universal, o que diz do humano - mas não nos deteremos nela. Nosso propósito é acompanhar as figuras femininas que correm paralelas a essa trajetória, possibilitando-a, e revelando muito sobre alguns rígidos lugares sociais reservados à mulher. Vale lembrar que esse romance foi escrito nos anos 1950, quando Clarice vivia com a família nos Estados Unidos, e publicado apenas em $1961^{5}$. O panorama social da época tem logicamente suas particularidades, mas para o que nos interessa aqui, não difere muito do que ainda vivemos.

\footnotetext{
${ }^{5}$ Clarice enfrentou muitas dificuldades para a publicação deste romance, como podemos ver em sua correspondência com Fernando Sabino (LISPECTOR, SABINO, 2011).
}

Filos. e Educ., Campinas, SP, v.11, n.1, p. 119-138, jan./abr. 2019 - ISSN 1984-9605 
Iniciemos então a análise dos perfis femininos de $A$ maçã no escuro, através de um breve relato da trama central do livro, que diz respeito ao personagem Martim. Os movimentos das personagens femininas estão sempre relacionados de algum modo a ele.

Martim, o protagonista, comete um crime e foge. Se esconde sozinho por algum tempo, até encontrar o sítio de Vitória onde vai se empregar e viver a maior parte de sua jornada. Tal jornada pode ser vista como um total despojamento de si mesmo e de sua própria história, com a consequente reconstrução de si e de seu mundo. O crime, para Martim em sua trajetória, tem o caráter de uma espécie de ponto de virada em sua vida, o ato necessário para que o processo transformador tivesse início, a "grande cólera", como vemos nesse trecho:

Imaginem uma pessoa que era pequena e não tinha força. Ela na certa sabia muito bem que toda a sua força reunida, tostão por tostão, só seria suficiente para comprar um único ato de cólera. E na certa também sabia que esse ato teria que ser bem rápido, antes que a coragem acabasse, e teria mesmo que ser histérico. Essa pessoa, então, quando menos esperava, executou esse ato; e nele investiu toda a sua pequena fortuna.

Bastante espantado com o que acabara de pensar, o homem se interrompeu com curiosidade: ‘então foi o que aconteceu?' Era a primeira vez que lhe ocorria. (LISPECTOR, 1998, p. 38)

Cabe aqui ressaltar a particularidade do crime cometido. $\mathrm{O}$ ato de cólera poderia ser qualquer um, mas o realizado é exatamente o assassinato da esposa por desconfiar que ela o traía, o que é revelado apenas no final do romance. Martim tenta matar sua esposa, foge acreditando que ela está morta, vive toda a sua transformação acreditando nisso, e no final descobre que ela tinha sobrevivido.

A primeira mulher que aqui nos interessa, então, é a esposa vítima da violência da tentativa de assassinato. "Era isso? Era só isso." (LISPECTOR, 1998, p. 297) Esse comentário nos revela a banalidade do assassinato de 
uma mulher, da própria esposa. O crime mais banal, o mais óbvio. Não me estendo sobre isso. Há que se fazer algum silêncio diante dessa realidade insistente.

Quero antes chamar a atenção para o fato de que não sabemos nada dessa mulher. A autora não nos revela quase nada sobre ela. A esposa de Martim não tem rosto ${ }^{6}$ em $A$ maçã no escuro. Sabemos apenas que foi vítima da violência do marido e que não revelou ao filho que o pai tinha tentado matá-la, mantendo intacta a imagem do pai para o filho (LISPECTOR, 1998, p. 302). Uma mulher sem rosto, apenas uma sombra obscura a revelar o perfil de vítima da violência e de protetora do violentador. Uma figura infelizmente por demais conhecida por todos nós, incrustada em um lugar social bastante comum. Ainda que a configuração social dessa realidade tenha se alterado ao longo desses sessenta anos que nos separam da escrita dessa história, muito há ainda a se vencer ${ }^{7}$.

Assim então se inicia a trajetória de Martim. Lança-se no lugar banal do marido traído e assassino - feminicida - e a partir disso desaparece de seu mundo habitual. Age banalmente para com a mulher que, para o leitor, não tem rosto. Lança-se em solidão para longe da cidade até encontrar um sítio onde pede emprego e pouso. Desde o momento em que foge e, principalmente, no tempo que mora e trabalha no sítio, passa a viver a desconstrução de si e de tudo o que dizia respeito a sua identidade social anterior.

No sítio vivem cinco pessoas. Apenas um homem, o trabalhador Francisco, que se vê em competição masculina com Martim. Nunca se relacionam para além do necessário nos trabalhos do sítio. A tensão entre eles permanece apenas insinuada ao longo do romance, desde a cena em que se vêem pela primeira vez (LISPECTOR, 1998, p. 54-57). Francisco é personagem secundário que não participará dos movimentos de transformação de Martim. As outras personagens, quatro mulheres: Vitória,

\footnotetext{
${ }^{6} \mathrm{E}$ aqui pode-se pensar, teoricamente, a partir da construção de Lévinas sobre o rosto como presença primeira da outra pessoa.

${ }^{7}$ Os índices de violência contra a mulher ainda são assustadores. Sobre os números de mulheres vítimas de violência no Brasil pode-se ver, por exemplo, no Mapa da Violência publicado em 2015 (WAISELFISZ, 2015).
} 
a proprietária, quem governa tudo por lá. Ermelinda, prima viúva de Vitória, vive com ela desde a morte do marido. A mulata, trabalhadora doméstica, empregada de Vitória. E a menina ${ }^{8}$, filha da mulata.

Martim, depois de um percurso solitário em que se põe em relação com pedras, plantas e animais ${ }^{9}$, redescobre um dia o desejo sexual. Aproxima-se então da mulata em busca de sexo. Vejamos:

O homem fingia estar interessado no trabalho, só para disfarçar.

(...)

Dois dias depois, em vez de ir ao curral, ele enfim se aproximou da mulher que lavava roupa. E ficou de pé sem olhá-la.

E sem olhá-lo, ela riu. Ele quebrou meticulosamente um graveto na mão, e sem fitá-la sabia que ela era moça. Seus cabelos tinham cachos duros, compridos. Como Martim era pessoa que gostava imediatamente do que precisava, ele a achou logo bonita. Afinal jogou o graveto longe e olhou-a de frente: seria largá-la ou pegá-la. Ele a pegou sem pressa como um dia pegara um passarinho.

(...)

Sentia o calor que vinha dela, e assim devia ser; corpo a corpo com o pulso mais íntimo do desconhecido.

Já era escuro quando seus gestos despertaram a moça nova. O homem acendeu a lamparina do depósito e ela deu um pequeno grito de raiva. O que quer que fosse se enroscara em cólera. Ele a olhou curioso. Ela vibrava de raiva, Deus sabe por quê.

E ele ficou sozinho, à porta do depósito.

Martim estava muito surpreendido porque antigamente ele costumava saber de tudo. (LISPECTOR, 1998, p. 106-107)

\footnotetext{
${ }^{8}$ Não trataremos aqui da figura da menina que, quando aparece de forma destacada no desenrolar da história, é muito mais como criança do que como menina-mulher (LISPECTOR, 1998, p. 202-206).

${ }^{9} \mathrm{Em}$ sua reconstrução, Martim parte das formas mais primárias da natureza, as pedras, com quem "dialoga" longamente (LISPECTOR, 1998, p. 37-48); as plantas que vivem dia a dia em seu silêncio no que chama de "terreno terciário", onde, durante longo período, permanece por horas em estado de quase meditação (LISPECTOR, 1998, p. 82-93); as vacas do curral que deve limpar, com quem entra em interação profunda, experimentando em si a vida animal (LISPECTOR, 1998, p. 94-98).
} 
Mais uma vez nos vemos diante de uma figura social velha conhecida: a mulata feita de objeto sexual. Se, no decorrer do processo de Martim, não surpreende que ele passe por um momento de (re)descoberta do outro pela via da sexualidade, não pode passar despercebido que a figura que provoque esse despertar seja uma mulata. A figura escolhida para retratar um momento de contato apenas sexual é a da mulata, revelando outro rígido lugar social longamente destinado à mulher.

No trecho copiado acima, entretanto, algo mais chama a atenção: o grito abafado de raiva da mulata, a raiva não explicada, a falta de palavras, a falta de possibilidade de dizer de si. A mulata, que não tem nome, também não tem voz. Agora então é a mulher sem voz que nos é apresentada. Sabemos dela um pouco mais do que sabíamos da esposa sem rosto, mas não muito mais. Sem voz, a mulata não se revela. Sabemos dela que é atraente, que ri e canta enquanto trabalha, que acede ao homem que a procura, que sente raiva quando ainda está com o homem, após o sexo realizado, e que não é compreendida por ele. Por um lado, ela nada diz e, por outro, Martim não entende nada do que ela poderia querer dizer, o grito não revela nada a ele. A comunicação ente eles é de total precariedade, se deu apenas entre os corpos não simbolizados pela palavra. Podemos inferir da passagem lida que essa relação ainda é de violência, o grito abafado da mulata o revela. A mulher vista apenas como corpo a ser possuído sexualmente, a mulher que não encontra a possibilidade de se expressar, calada na sua raiva, essa é a mulata. Sabemos que ela não foi literalmente violentada sexualmente, ela acede e vai para o ato de livre vontade. Mas aqui poderíamos nos estender muito sobre a palavra "livre" na frase acima. Temos visto repetidamente a defesa de um agressor se construir através do recurso a uma alegada livre escolha da vítima ${ }^{10}$. Ainda assim, a violência se revela na impossibilidade de se expressar da mulher. Trata-se de uma situação de violência que vai além do enquadramento particular da cena

\footnotetext{
${ }^{10}$ Cabem aí todas as tentativas de culpabilização da vítima agredida devido ao modo como se veste, ao horário em que está fora de casa, ao fato de estar sem companhia (masculina, é claro), etc, etc, etc. Para não dizer das infindáveis histórias de assédios sofisticadamente dissimulados que acabam por envolver a vítima "livremente".
}

Filos. e Educ., Campinas, SP, v.11, n.1, p. 119-138, jan./abr. 2019 - ISSN 1984-9605 
narrada. Mesmo que Martim não a tenha violentado fisicamente, a violência lá está.

Mas sigamos em nossa análise.

Ermelinda, a prima viúva que vivia no sítio por não ter outra opção, é descrita como uma mulher infantilizada. Não participa dos trabalhos do sítio, passa os dias à espera do dia seguinte. Vitória a trata com impaciência e nunca leva em conta o que ela diz. É sempre assombrada por muitos medos, em especial o medo da morte. Ermelinda veio perturbar a calma buscada por Vitória na vida no sítio. Perturba-a com seu modo descabido de ver as coisas, dizendo frases tidas por Vitória como carentes de racionalidade (LISPECTOR, 1998, p. 77). Em outros momentos, Vitória se irrita pelo excesso de entusiasmo que a prima demonstra diante de qualquer acontecimento, o que a leva a hesitar em contar que contratou um novo trabalhador, já prevendo a exaltação da moça. Vejamos o diálogo em que a presença de Martim, que usará um depósito de lenha como quarto, é revelada a Ermelinda, para que possamos perceber o tom da relação entre as primas:

Vitória fechou as mãos dentro dos bolsos da calça:

- Que é que você está fazendo, perguntou tranquila.

- Podando a roseira brava.

- A roseira não assusta você? Perguntou suave; tinha necessidade de ferir aquela moça ajoelhada como se esta fosse a culpada do absurdo dela própria ter contratado o homem.

- Esta não: esta tem espinhos.

Vitória franziu as sobrancelhas:

- E que diferença faz se tem espinhos?

- É que só tenho medo, disse Ermelinda com certa voluptuosidade, quando uma flor é bonita demais: sem espinho, toda delicada demais, e toda bonita demais.

- Não seja tola, disse Vitória com brutalidade, é de qualquer modo no corpo que se passam as coisas! E se você ajudasse nos trabalhos não teria tempo de ter horror de rosas bonitas ou de detestar a fazenda!

-E você, gosta muito da fazenda? perguntou a outra maciamente. 
- Tem um homem no depósito de lenha! cortou Vitória. (LISPECTOR, 1998, p. 75)

Pois bem, Ermelinda, tida por Vitória como tola, assustada com a beleza excessiva, entretida com as flores e os pássaros, rapidamente se apaixona por Martim (LISPECTOR, 1998, p. 85). Passa a rondá-lo por onde pode. Ele, sempre cumprindo as ordens de Vitória, demora a se dar conta da presença constante da outra. Depois de longa aproximação, acabam se envolvendo. Nos vários encontros entre os dois, Ermelinda se mostra para Martim com fragilidade, medo, romantismo ingênuo, encantamento por coisas banais. É também capaz de ser feliz e de se alegrar com pouco. Martim, como Vitória, não considera realmente o que ela fala, mas a protege, a escuta com condescendência como se faz com uma criança. O afeto que sente por ela se manifesta nessa proteção que é como uma salvaguarda para que ela possa existir, o que podemos ver nesse diálogo que acontece um pouco antes da aproximação amorosa:

- O senhor pode pensar que sou doida, disse-lhe com o ar persistente dos cegos, mas tem um lugar dentro de mim onde vou quando quero dormir! ah, eu sei que isso é engraçado, mas é assim... Se esse lugar fosse perto, eu até podia dizer que ficava no canto esquerdo de minha cabeça - é que eu durmo deitada do lado esquerdo, explicou-lhe de passagem, lambendo os lábios - mas esse lugar é tão mais longe, é como se fosse muito depois que eu acabo... mas é ainda dentro de mim, sou eu ainda, entendeu?

(...)

- É doida porque fala, disse ele afinal, pesado.

- Ah, disse ela com o ar sabido de quem não se deixaria enganar, então já estou vendo tudo: você acha que sou doida! já vi tudo, você não me engana! disse toda risonha usando o 'você' com intenção — mas seus olhos abertos estavam pensando em outra coisa.

(...)

— Não, repetiu então olhando-a, e com um primeiro carinho de curiosidade na voz, você não é doida. É que você vive muito isolada e já 
não sabe mais o que se conta aos outros e o que não se conta - o homem parou e olhou-a, intrigado por ter falado tanto.

Ele nunca falara tanto, e o coração da moça começou a bater:

— Pois é, disse ela galante. (LISPECTOR, 1998, p. 124-126)

Ermelinda é, pois, uma mulher sem razão. Sem razão, aqui, se refere à desconsideração do outro em relação ao conteúdo do que fala; tudo o que diz parece ser, para Vitória e Martim, sem sentido, irrazoado. Martim, porém, a aceita e a coloca a salvo do olhar constante de Vitória, que não aceita essa condição da prima e a critica permanentemente ${ }^{11}$. Ermelinda, embora desconsiderada em sua racionalidade, encontra guarida para seu modo de ser na proteção masculina. Vejamos uma cena que revela esse movimento:

A curiosidade de Martim, agora acrescida de ignorância, aumentou cega, instintiva. Ele havia largado sua mão quando a sentira tão fria - mas dessa vez foi sem esforço que de novo a pegou. E a mão pequena era leve entre as suas mãos endurecidas por aqueles calos de que ele se orgulhava e que ali estavam como um estigma. O orgulho de si mesmo então emocionou-o muito. E com o orgulho ele podia pegar naquela mão com segurança.

Quando um homem e uma mulher estão perto e a mulher sente que ela é uma mulher e o homem sente que ele é um homem - isso é amor? O sol a cento e cinquenta milhões de quilômetros queimava a cabeça de ambos. 'Oh, livre-me do meu mistério!', implorou-lhe ela por dentro. (LISPECTOR, 1998, p. 162)

Ermelinda, cuja complexidade podemos perceber no trecho acima, é também trazida à cena em momentos em que dialoga consigo mesma. $\mathrm{O}$ medo/atração que sente pela morte, os caminhos tortuosos que seu pensamento percorre, o desassossego que a toma podem ser sentidos nessa passagem: 252.

${ }^{11}$ Pode-se perceber essa dinâmica no diálogo entre Vitória e Martim às páginas 251-

Filos. e Educ., Campinas, SP, v.11, n.1, p. 119-138, jan./abr. 2019 - ISSN 1984-9605 
Todo o trabalho daquela moça, que tinha uma vez caído no mistério de pensar, era procurar inutilmente provas de que a morte seria o sereno fim total. E isto seria a salvação, e ela ganharia a sua vida. Mas, com sua tendência para a minúcia, o que conseguia eram os indícios contrários. Uma galinha que voava mais alto que o comum - tinha aquela naturalidade do sobrenatural. Cabelos que cresciam sempre tão depressa tornavam-na pensativa. (...) ... tudo isso obscuramente era um indício de que depois da morte começava a vida incomensurável. (LISPECTOR, 1998, p. 241)

Desassossegada, Ermelinda sonha com a morte definitiva, mas teme a morte por desconfiar - devido aos "sinais" - de que não haverá o descanso final, de que a vida sempre se renovará, e isso a assusta. De modo que percebemos que, mais do que temer a morte, ela teme a "outra vida"; teme o excesso de vida, como vimos no medo das flores "bonitas demais". Vemos que a personagem se complexifica à medida que nos aproximamos, mas aqui podemos também perceber no desejo de sossego a alegria da proteção encontrada em Martim:

A moça pegou na mão dele e sentindo-a quente e ainda molhada, suspirou profundamente e deu uma risadinha. É que mal acreditava na própria esperteza: esta noite ela vencera o medo. E mesmo atordoada pelo sono soubera correr para perto de um homem, pois um homem não tinha a suavidade das mulheres, um homem desmentia por um instante a outra vida. (LISPECTOR, 1998, p. 243)

O homem, então, surge como saída para o medo que sentia. Ainda que instantaneamente, com Martim Ermelinda sossegava.

Vale ressaltar que a desrazão de Ermelinda é sossego também para Martim que, ao não se sentir interpelado racionalmente por ela, se protege de sua própria limitação, como vemos neste trecho: 
Mas a verdade é que para ele era um repouso ter aquela mulher que se dava fácil, como se tê-la à sua disposição já fosse um marco alcançado: até aí ele já dominara. Quanto mais tola, mais dele ela era: ela compensava a dificuldade que Martim estava tendo consigo mesmo. (LISPECTOR, 1998, p. 183)

Com a descrição feita, mais uma vez estamos diante de uma figura facilmente encontrada nos rígidos lugares sociais que têm abrigado a mulher. Frágil, infantil, sem capacidade racional, cheia de sonhos, principalmente em relação ao amor, tratada pelo homem com condescendência, mas nunca com reconhecimento de sua condição de igualdade frente a ele. Ela tem rosto e voz, mas não tem razão - ou a razão nela percorre outros caminhos, que não os desejados pela racionalidade hegemônica; Martim a vê e a escuta, mas não a considera. Ainda que tenha uma experiência existencial complexa e singular, isso não é reconhecido. O que aparece socialmente é o medo e a fragilidade.

Chegamos então a Vitória. Senhora absoluta da fazenda e de tudo o que acontece por lá, aceita desde o início a presença de Martim com desconfiança. Nunca o perde de vista e é quem leva a cabo a ideia de denunciá-lo, suspeitando sempre de algo errado com ele.

Vive na fazenda há muitos anos, desde a morte do pai. Desde então, sempre comandou tudo sozinha. Desde a chegada de Martim, dá ordens a ele incessantemente, e muitas mudanças foram se fazendo por lá. A presença dele a incomoda e intriga, e gera transformação, não só no espaço, mas também nela própria. Martim parece representar o não controlado, aquilo que ela não consegue prever e nem dominar, apesar da cega obediência dele em relação às ordens de trabalho que ela lhe dá.

Vitória, forte, segura, cheia de domínio sobre si mesma e sobre o que está em volta, aparece como masculinizada. Sempre com roupas de trabalho, causa estranhamento quando, a certo ponto da narrativa, aparece com "vestidos agora femininos" (LISPECTOR, 1998, p. 287). Parecia, neste ponto, descansar depois de muito trabalho realizado e depois de ter se revelado um tanto para Martim quando, pouco antes da cena final do 
romance, o envolve em uma tarefa interminável de derrubar uma macieira, e o obriga a escutá-la em relatos sobre seu passado (LISPECTOR, 1998, p. 247-287). Fala da vez em que amou um homem, e é um relato infantil, como uma história típica de Ermelinda. Por outro lado se refere à prima como frágil demais para o amor, e se assusta pelo medo de que Martim pense que ela está dizendo que é forte para o amor, pois não admite nenhuma insinuação nesse sentido. Vejamos:

- (...) Ermelinda poderia corresponder, digamos, mesmo ao amor, mas ela não resistiria. Ermelinda tem a doença da alma, como se diz... (...)

(...)

- Tudo em Ermelinda é por um fio! gritou-lhe como numa ordem final.

- E na senhora? indagou ele muito calmo.

Antes mesmo de sentir a pergunta com um pequeno choque, pelo que esta implicava em ofensa pessoal, Vitória se descrispou toda: era suave ouvi-lo falar nela. "A senhora, a senhora, a senhora." A palavra respeitosa e doce quebrava enfim alguma trama no seu peito, ela que sempre tivera medo de não ser respeitada.

- Eu não, respondeu sem vaidade. Eu sou forte.

Um instante mais, e ocorreu-lhe que na verdade acabara de dizer ao homem que ela era forte a ponto de suportar o amor. Teria ela simplesmente se oferecido a ele? Seus olhos piscaram várias vezes como se a esse pensamento eles tivessem ficado cegos de surpresa. Como falava pouco, já não sabia até que ponto as palavras costumavam revelar o pensamento, e seu coração bateu de horror: teria o homem compreendido? E o pior, pensou ela em revolta, é que era mentira: não era amor que ela queria!

No rosto calado de Martim afortunadamente a expressão era vazia. Ela tivera medo de que ele demonstrasse que compreendera. E logo em seguida, por um instante, ela quis que exatamente isto sucedesse: que ele dissesse que compreendera e que tudo desabasse enfim. No instante seguinte ela o mataria se ele ousasse compreender. Não tolerava a ideia 
de que ele achasse óbvio que ela o amasse, sobretudo porque não era verdade, revoltou-se ela. (LISPECTOR, 1998, p. 254-255)

Nesta passagem podemos ver a tensão da posição de Vitória: potente em impor respeito, nega o próprio desejo, como se desejar amor a fragilizasse. Vitória é a mulher sem desejo. Ou antes, sem o reconhecimento do desejo. É forte, poderosa, se faz presente em rosto, voz e razão, mas não encontra lugar para o desejo. A potência nela é toda voltada para o comando e para se impor diante da realidade pouco amistosa. Essa figura também não nos é socialmente estranha. Trata-se da mulher que, para se fazer considerar pelo entorno social que não quer considerá-la, se põe permanentemente em luta.

Martim, diante dela, obedece. E respeita. Ainda que pareça não se interessar quando ela quer falar de si, não deixa de escutar e considerar. Mais do respeito, sente medo, pois sabe que ela pode entregá-lo às autoridades, sabe que ela tem capacidade racional para perceber algo sobre ele próprio que ele não tem a intenção de mostrar. Num jogo em que os dois têm a pretensão de controlar a situação, Vitória como proprietária e comandante da fazenda, Martim como o foragido que calcula a cada instante os riscos que corre, um sabe que pode deixar de perceber algo e que o outro pode perceber mais. Estão em igualdade de condições como pessoas com rosto, voz e razão. E, neste sentido, masculinizada, a mulher não se encontra em sua potência carnal de ser que deseja. Masculinizada aqui se refere ao fato de que Vitória, para ter tanta potência social quanto um homem, perde a si mesma de vista como mulher.

Nas últimas páginas do romance, entretanto, uma cena entre Martim e Vitória nos aponta uma reviravolta possível para o destino feminino. No momento em que se despede de Vitória, Martim se ajoelha e pede perdão, repetidamente. Vejamos uma cena talvez excessivamente longa, mas necessária para a compreensão do desenlace deste texto:

- Magoei-a?! gritou ele.

- Não, não! protestou ela aterrorizada. 
Então ficaram em silêncio.

(...)

- A senhora me desculpe eu não ter...- e o pior do que ele disse felizmente não se conseguiu mais ouvir como se a paralisia já tivesse avançado até aquela boca entortada pela piedade.

(...)

- Desculpe eu não ter..., murmurou ele se escusando como um impotente.

(...)

Então Martim se ajoelhou diante dela e disse:

- Perdoe.

(...)

Mas a mulher de repente segurou num movimento incoercível o ventre com as mãos, lá onde dói uma mulher, sua boca estremeceu atingida, o futuro era um parto difícil: num movimento de animal ela apertou o ventre, onde por um destino uma mulher dói, e a alegria era tal miséria, sua boca estremeceu pobre, atingida.

- Que é que o senhor está fazendo! disse-lhe austera como se o erguesse.

O homem se levantou, limpou as calças. A mulher ergueu mais a cabeça. E foi só então que estranharam.

Mas então já era felizmente tarde demais: alguma coisa essencial se tinha feito. O que realmente acontecera - não se sabe, sobretudo nenhum dos dois sabia, a gente substitui muito. Acontecera algo essencial que eles não compreendiam e estranhavam, e que possivelmente não é para ser compreendido, quem sabe se o essencial não foi destinado a ser compreendido, se somos cegos por que insistimos em ver com os olhos, por que não tentamos usar estas nossas mãos entortadas por dedos? por que tentamos ouvir com os ouvidos o que não é som? E por que tentamos, de novo e de novo, a porta da compreensão? o essencial é destinado apenas a se cumprir, glória a Deus, amém. E um dos indiretos modos de entender é achar bonito. Do lugar onde estou de pé, a vida é muito bonita. Um homem, impotente como uma pessoa, se ajoelhara. Uma mulher, ofendida no seu destino, erguera a cabeça sacrificada pelo 
perdão. E, por Deus, algo acontecera. Algo acontecera com cuidado, para não ferir a nossa modéstia.

Os dois evitaram se olhar, emocionados com eles próprios, como se enfim fizessem parte daquela coisa maior que às vezes chega a conseguir se exprimir na tragédia. Como se houvesse atos que realizam tudo o que não se pode, e o ato transpõe o poder; e quando este se cumpre, realiza-se alguma coisa que o pensamento não faria, nós que somos de uma perfeição atroz - e a dor é que não estamos à altura de nossa perfeição; e quanto à nossa beleza, nós mal a suportamos - Martim, por exemplo, olhou neste momento para os sapatos, oh por que disfarçamos tanto? encabulado na hora de sua morte, ele seria capaz de disfarçar assobiando. Como se tivessem acabado de realizar de novo o milagre do perdão, constrangidos com aquela cena miserável, evitaram se olhar, aborrecidos, há muita coisa inestética a perdoar. Mas, mesmo coberta de ridículo e de trapos, a mímica da ressurreição se tinha feito. Essas coisas que parecem não acontecer, mas acontecem. (LISPECTOR, 1998, p. 325-326)

O pedido de "perdão por não..." aponta para o desejo. Poderíamos completar 'perdão por não ter visto seu desejo', ou 'perdão por não ter te desejado', ou ainda 'perdão por não ter te tocado'. Vitória se perturba e não demonstra saber do que ele está falando. Mas a narração segue em extrema tensão poética, revelando que algo desconhecido acontecera. Permanece desconhecido porque "substituímos muito", isto é, não conseguimos ver o essencial, disfarçamos, entendemos outra coisa, ou não entendemos nada. O que ali aconteceu, na medida em que não é revelado explicitamente pelo texto, é campo aberto à interpretação. Penso que ali se deu o reconhecimento masculino da dor causada à mulher pela recusa em lhe ver em rosto, voz, razão e desejo, como num pedido de perdão não só a Vitória, mas a todas as mulheres, numa chave mítica em que o Homem se dirige à Mulher, e a recepção feminina muda e perplexa deste reconhecimento. Importante notar também que Martim se faz "impotente como uma pessoa", ou seja, o universalizável aqui, o que diz da "pessoa" humana, é a impotência, de modo que podemos entender que a perda de potência por 
parte do homem faz parte desse caminho de percepção e aceitação da mulher em sua totalidade.

O reconhecimento e a aceitação do desejo por Vitória, diante do homem agora humanamente impotente, seria, pois, a saída para que a mulher encontre uma vereda para a felicidade possível. O desejo da mulher que tem rosto, voz e razão.

Martim, diante das diferentes figuras de mulher, reagiu a cada uma delas do modo socialmente esperado. A mulher sem rosto, não vista em si mesma, cujo desejo só é percebido em relação ao outro - medo da traição -, ele tenta matar. Com a mulher sem voz, não escutada, que ele deseja como corpo e da qual só vê também o desejo do corpo, ele se relaciona sexualmente, sem ouvi-la, num sexo sem palavras. Com a mulher infantilizada, cuja razão não é considerada, ele se relaciona sexual e amorosamente de forma protetora, numa relação desproporcional, entre desiguais. Diante da mulher potente, ele se relaciona de igual para igual, mas sem sexualidade; o desejo, dela e dele, permanece oculto. O pedido de perdão aponta para a possibilidade não vivida, a possibilidade do sexo amoroso com rosto, voz e razão, entre iguais, impotentes como duas pessoas.

Chegamos aqui à figuração de um ser sem rosto, sem voz, sem razão, sem desejo colocado diante de um outro que é o que pode lhe devolver estas ausências através da própria transformação. Se a luta feminista caminha sempre no sentido da libertação da mulher através de seus próprios recursos - que são aqueles de toda pessoa humana - é também patente que esta luta só vai ser plenamente vitoriosa quando o homem também for libertado/transformado. Aqui tocamos mais uma vez no referencial freiriano que afirma que a libertação do oprimido é também a libertação do opressor na construção de uma outra forma de relação que não seja a da opressão (Freire, 1987). A mulher, particular universalizável do humano, terá sua condição humana plenamente aberta como um horizonte quando for vista por todos os outros - humanos como ela - como um ser com rosto, voz, razão e desejo. Um ser corporificado, cuja simples presença já abre para 
quem o vê a possibilidade de vislumbre do outro. Um ser que, na presença, se revela pela linguagem, capaz de comunicação. Que, ao revelar-se falando, mostra que é um ser de razão, o que potencializa a comunicação e a construção da compreensão do mundo e de si. E que, com o impulso que o põe em movimento, e todo o universo de sensibilização que tal movimento desperta, é um ser que deseja, que se coloca frente ao outro em busca do encontro. Penso que há no desenlace de A maçã no escuro, uma postulação utópica a ser perseguida: o encontro igualitário entre homens e mulheres cis ou trans, e ainda os indefinidos - no reconhecimento, por parte da pessoa humana, do outro como um ser que, mesmo diferente nas particularidades, lhe é em tudo semelhante na humanidade. Tal postulação nos coloca no universo da ética, em que as exigências de universalidade jamais poderão ser ultrapassadas.

Penso que hoje, seis décadas depois da escrita deste romance, ainda que individualmente muitas mulheres e homens tenham atingido essa possibilidade, coletivamente ainda caminhamos lentamente à sua procura, nos defrontando incessantemente com impedimentos e retrocessos, na medida em que a opressão, a exploração e a negação do outro ainda são a marca preponderante das relações sociais no contexto capitalista patriarcal, marcado pelo machismo, pelo racismo, pela homofobia, pelo descarte e/ou tentativa de cooptação de tudo o que não é idêntico ao normalizado pelas estruturas de poder.

\section{REFERÊNCIAS:}

CIXOUS, Hélène. Entre l'écriture. Paris: Des femmes, 1986.

CIXOUS, Hélène. L'Heure de Clarice Lispector. Paris: Des femmes, 1989.

DEMÉTRIO, Alana Kercia Barros e COSTA, Maria Helenice Araújo. "Linguagem, cognição e referência, em A maçã no escuro", in Acta Scientiarum - Language and Culture, vol. 37, n 4, pp. 381-391, Maringá, out/dez 2015. 
FREIRE, Paulo. Pedagogia do oprimido. $17^{a}$ edição. Rio de Janeiro: Paz e Terra, 1987.

LISPECTOR, Clarice. A maçã no escuro. (1961) Rio de Janeiro: Rocco, 1998.

LISPECTOR, Clarice. Uma aprendizagem on o livro dos prazeres. Rio de Janeiro: (1969) Rocco, 1998

LISPECTOR, Clarice, SABINO, Fernando. Cartas perto do coração. (2001)

Rio de Janeiro: Record, 2011.

NUNES, Benedito. Leitura de Clarice Lispector. Coleção Escritores Hoje, São Paulo, Quíron, 1973.

NUNES, Benedito. O dorso do tigre. Ensaios. São Paulo: Perspectiva, 1969.

PIRES, Mirian da Silva. "As margens filosóficas no romance $A$ maçã no escuro, de Clarice Lispector". Site $O$ Marrare. http://www.omarrare.uerj.br/numero13/mirian.html (acesso em $15 / 5 / 18)$.

TADA, Elton Vinícius Sadao. A coragem de Clarice: Experiência e Religião. São Paulo: Loyola, 2017.

VIEIRA, Júlio César e OLIVA, Osmar Pereira. "Crime e libertação - Um estudo de A maşã no escuro, de Clarice Lispector", in Revista de Letras, vol. 51, no 2, pp. 171-190, São Paulo, jul/dez 2011.

WAISELFISZ, JulioJacobo. Mapa da violência 2015 - Homicídios de mulheres no Brasil. Disponível em: https://apublica.org/wpcontent/uploads/2016/03/MapaViolencia_2015_mulheres.pdf (acesso em 14/11/2017).

Submetido em: 15/08/2019

Aceito em: 15/09/2019

Publicado em: 30/10/2019 